\title{
A Study of Small Particle Yttrium Oxide Type Phosphors prepared from Solution using a Sacrificial Micellar Phase as a Combustion Fuel
}

\author{
K. Saltoun, T.G. Ireland, G.R. Fern, R. Withnall, and J. Silver \\ Centre for Phosphors and Display Materials, Wolfson Centre for Materials Processing, Brunel University, \\ Kingston Lane, Uxbridge, Middlesex UB8 3PH, UK; Email Robert.Withnall@brunel.ac.uk
}

\section{INTRODUCTION}

In 1999 the facile self-assembly of the red emitting phosphor yttrium oxide europium $\left(\mathrm{Y}_{2} \mathrm{O}_{3}: \mathrm{Eu}^{3+}\right)$ from solution using a sacrificial micellar phase was reported. The micellar phase was assembled using the alkyl ammonium salt $\left(\mathrm{C}_{12} \mathrm{H}_{25} \mathrm{NH}_{3}\right) \mathrm{Cl}$ in an ethanolic solution. The resulting fine powder had smaller particles, ranging in size from 0.1 to $1.0 \mu \mathrm{m}$, than the commercial cubic $\mathrm{Y}_{2} \mathrm{O}_{3}: \mathrm{Eu}^{3+}$ phosphor. ${ }^{1}$ In this work we used a longer chained aliphatic amine, $\mathrm{C}_{16} \mathrm{H}_{33} \mathrm{NH}_{2}$, as fuel.

\section{RESULTS AND DISCUSSION}

A typical preparation was carried out using the following method. A warm ethanolic solution of $\mathrm{YCl}_{3}(55.37 \mathrm{~g}$, in $25 \mathrm{ml}, 0.25 \mathrm{M})$ and $\mathrm{EuCl}_{3}(1.76 \mathrm{~g}$ in $25 \mathrm{ml}$, $0.02 \mathrm{M}$ ) was added to a warm solution of $\mathrm{C}_{16} \mathrm{H}_{33} \mathrm{NH}_{3} \mathrm{Cl}$ in ethanol. This gave a stoichiometric ratio of $1: 1$ for the combined metal chloride to alkylammonium chloride present in the solution. In other preparations the metal chloride to alkylammonium chloride ratio was 1:3. The solution was heated on a hot plate to about $100^{\circ} \mathrm{C}$ where the initial yellow colour disappeared and the solution was reduced in volume until it became viscous and a pale yellow mass was then apparent. A portion of each product was then fired in a furnace (wherein the temperature was either set at $650^{\circ} \mathrm{C}$ or $900^{\circ} \mathrm{C}$ ) for $30 \mathrm{~min}$. This allowed the combustion of the alkylammonium chains.

For the samples that were produced at the furnace set temperature of $650^{\circ} \mathrm{C}$, there was no evidence for cubic $\mathrm{Y}_{2} \mathrm{O}_{3}: \mathrm{Eu}^{3+}$. On the other hand, the samples that were produced at the furnace set temperature of $900^{\circ} \mathrm{C}$ showed the presence of crystalline material and they showed a Raman spectrum and X-ray powder diffraction pattern identified as cubic $\mathrm{Y}_{2} \mathrm{O}_{3}: \mathrm{Eu}^{3+}$. 


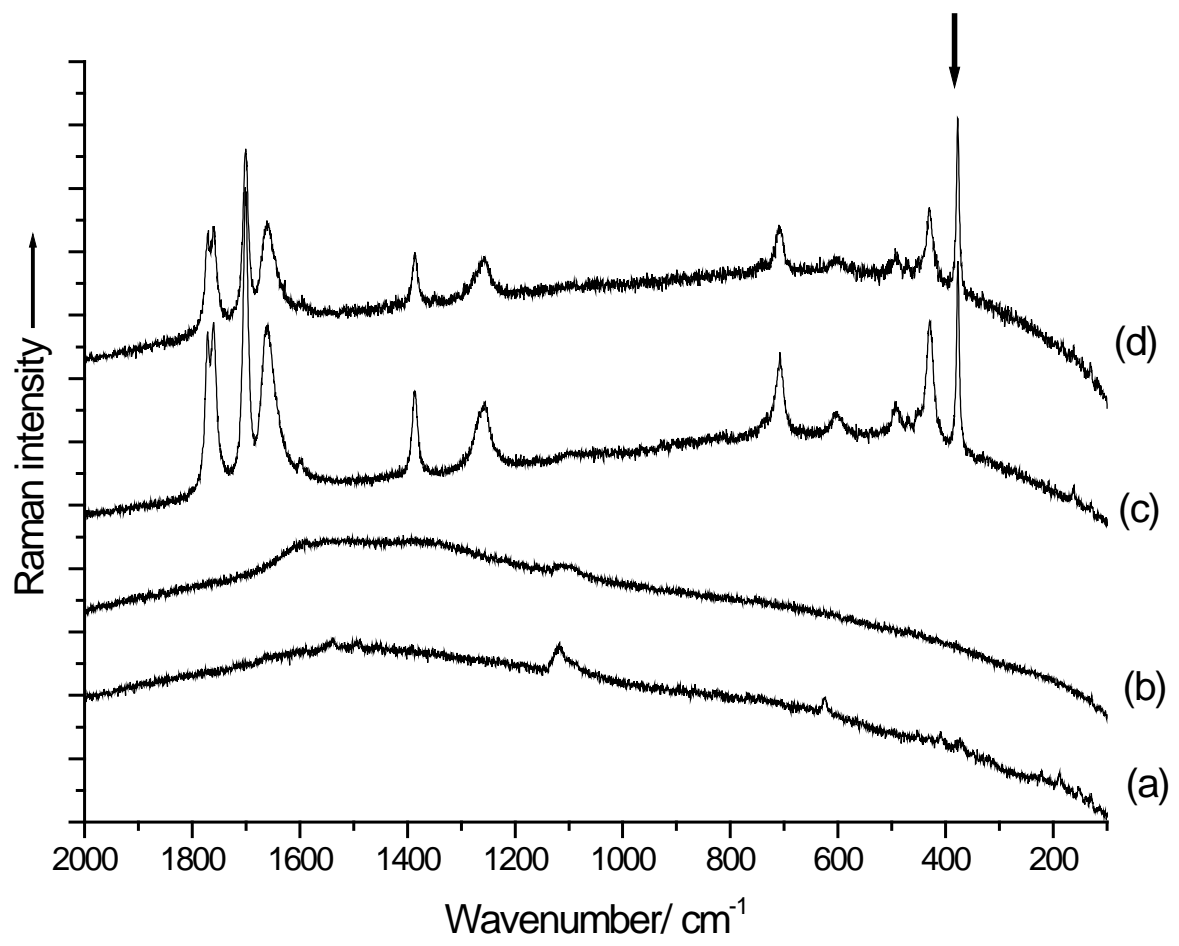

FIGURE 1. Raman spectra of phosphor samples prepared at metal chloride to alkylammonium chloride ratios of:- (a) $1: 1$ and fired at $650^{\circ} \mathrm{C}$, (b) $1: 3$ and fired at $650^{\circ} \mathrm{C}$, (c) $1: 1$ and fired at $900^{\circ} \mathrm{C}$, and (d) $1: 3$ and fired at $900^{\circ} \mathrm{C}$. The exciting wavelength was equal to $632.8 \mathrm{~nm}$.

As can be seen from the Raman spectra shown in Figure 1, a strong Raman band at $377 \mathrm{~cm}^{-1}$ (arrowed in Figure 1) is absent when the phosphor nanoparticles are fired at $650^{\circ} \mathrm{C}$ (see Figures 1a and 1b), but appears when the phosphor nanoparticles are fired at $900^{\circ} \mathrm{C}$ (see Figures 1c and 1d). This band is due to the cubic phase of $\mathrm{Y}_{2} \mathrm{O}_{3}: \mathrm{Eu}$. In addition, a number of other strong bands also appear in Figures 1c and 1d; these are due to the photoluminescence of the $\mathrm{Y}_{2} \mathrm{O}_{3}$ :Eu phosphors under $632.8 \mathrm{~nm}$ excitation.

In conclusion, when the oven temperature was set at $900^{\circ} \mathrm{C}$ (but not at $650^{\circ} \mathrm{C}$ ), the combustion fuel present in the samples was sufficient to raise the temperature over $900^{\circ} \mathrm{C}$ for a long enough time period for nanometer sized crystallites of the cubic $\mathrm{Y}_{2} \mathrm{O}_{3}: \mathrm{Eu}^{3+}$ phase to form.

\section{REFERENCES}

1. T.G. Ireland, J, Silver, C. Gibbons and A. Vecht, Electrochem.and Solid State Letts., 2, 52-54, (1999). 